\title{
MEFENPYR-Diethyl ACTION ON FENOXAPROP-P-ETHYL DETOXIFICATION IN WHEAT VARIETIES ${ }^{1}$
}

\author{
Ação de Mefenpyr-Diethyl sobre a Desintoxicação de Fenoxaprop-P-Ethyl em Variedades de \\ Trigo
}

\author{
CATANEO, A.C. ${ }^{2}$, FERREIRA, L.C. ${ }^{3}$, MISCHAN, M.M. ${ }^{4}$, VELINI, E.D. ${ }^{5}$, CORNIANI, N. ${ }^{6}$, and \\ CERDEIRA, A.L. ${ }^{7}$
}

\begin{abstract}
Safeners protect crops against herbicide injury. The aim of this study was to examine the differential susceptibility of five wheat (Triticum aestivum) varieties to the herbicide fenoxaprop-p-ethyl, as well as the performance of mefenpyr-diethyl on minimizing herbicide injury and on lipid contents. Varieties BRS 49, CD 104, CEP 24, IAPAR 78 and Rubi were sprayed with fenoxaprop-p-ethyl (69 $\mathrm{g} \mathrm{ha}^{1}$ ), fenoxaprop-p-ethyl + mefenpyr-diethyl $\left(69 \mathrm{~g}+18.75 \mathrm{~g} \mathrm{ha}^{-1}\right)$, or mefenpyr-diethyl $\left(18.75 \mathrm{~g} \mathrm{ha}^{-1}\right)$. Plants were evaluated visually for injury at 7 and 14 days after treatment (DAT). Glutathione S-transferase (GST) activity was assayed in aerial parts at 7 DAT, and lipid content was measured at 14 DAT. Varieties CEP 24, IAPAR 78 and Rubi were more tolerant to fenoxaprop-p-ethyl than BRS 49, and CD 104 rapidly recovering from the slight phytotoxicity symptoms produced by the herbicide. Mefenpyr-diethyl prevented crop injury associated with the herbicide. GST activity did not correlate directly with fenoxaprop-p-ethyl detoxification. However, lipid content was related to the susceptibility of wheat to fenoxaprop-p-ethyl treatment.
\end{abstract}

Keywords: safener, Triticum aestivum, selectivity, glutathione S-transferase, lipid content

\begin{abstract}
RESUMO - Protetores ou safeners protegem culturas contra a injúria de herbicidas. O propósito deste estudo foi investigar a suscetibilidade diferencial de cinco variedades de trigo (Triticum aestivum) ao herbicida fenoxaprop-p-ethyl e o efeito do protetor mefenpyr-diethyl na minimização da injúria do herbicida e sobre o conteúdo de lipidios. As variedades BRS 49, CD 104, CEP 24, IAPAR 78 e Rubi foram pulverizadas com fenoxaprop-p-ethyl (69 $\left.\mathrm{g} \mathrm{ha} \mathrm{h}^{-1}\right)$, fenoxaprop-p-ethyl + mefenpyr-diethyl (69 $\left.\mathrm{g}+18,75 \mathrm{~g} \mathrm{ha}{ }^{1}\right)$ ou mefenpyr-diethyl (18,75 $\mathrm{g}$ ha $\left.{ }^{1}\right)$. A injúria das plantas foi avaliada visualmente aos 7 e 14 dias após o tratamento (DAT). A atividade da glutationa S-transferase (GST) foi analisada na parte aérea aos 7 DAT, e o conteúdo de lipídios, aos 14 DAT. As variedades CEP 24, IAPAR 78 e Rubi foram mais tolerantes ao fenoxaprop-p-ethyl do que a BRS 49, e a variedade $C D 104$ rapidamente se recuperou dos sintomas de intoxicação produzidos pelo herbicida. Mefenpyrdiethyl preveniu a injúria da cultura pelo herbicida. A atividade da GST não foi correlacionada diretamente com a desintoxicação do fenoxaprop-p-ethyl. Contudo, o conteúdo de lipidios esteve relacionado à suscetibilidade de trigo ao tratamento de fenoxaprop-p-ethyl.
\end{abstract}

Palavras-chave: safener, Triticum aestivum, seletividade, glutationa S-transferase, conteúdo de lipídios.

1 Recebido para publicação em 8.8.2012 e aprovado em 25.10.2012.

2 Professora Adjunta, Dep. de Química e Bioquímica, Instituto de Biociências, UNESP, Botucatu-SP, Brasil, <acataneo@ibb.unesp.br>; ${ }^{3}$ Doutor em Ciências Biológicas, Botânica, Instituto de Biociências, UNESP, Botucatu-SP, Brasil, $<$ ferreira.leonardocesar@gmail.com>; ${ }^{4}$ Doutora, Dep. de Bioestatística, Instituto de Biociências, UNESP, Botucatu-SP, Brasil, $<$ mmischan@ibb.unesp.br>; 5 Professor Adjunto, Dep. de Agricultura, Faculdade de Ciências Agronômicas, UNESP Botucatu-SP, Brasil, <velini@fca.unesp.br>; ${ }^{6}$ Mestre em Ciência Florestal, Faculdade de Ciências Agronômicas, UNESP Botucatu-SP, Brasil, $<$ nataliacorniani@yahoo.com.br>; ${ }^{7}$ Doutor, Embrapa Meio Ambiente, Jaguariúna-SP, Brasil, <cerdeira@cnpma.embrapa.br>, $<$ acataneo@ibb.unesp.br>, autor para correspondência.

Planta Daninha, Viçosa-MG, v. 31, n. 2, p. 387-393, 2013 


\section{INTRODUCTION}

Herbicide fenoxaprop- $p$-ethyl, D - (+) - $2-4$ - (6-chloro - 1, 3 - benzoxazol - 2pyloxy) phenoxypropionacid is a member of the aryloxyphenoxy propionic acid chemical family. The target site of this herbicide is acetyl coenzyme A carboxylase, which catalyzes the ATP-dependent carboxylation of acetyl-CoA to form malonyl-CoA. This reaction is the first step in the de novo biosynthesis of fatty acids in plants (Gronwald, 1991).

Some Poaceae crops may be protected from herbicide injury by chemicals called safeners, which have little intrinsic biological activity. Safeners, also known as antidotes, belong to well-defined chemical classes and are applied either as seed treatment or directly as tank mixes with the herbicides (Abu-Qare \& Duncan, 2002). Thus, safeners reduce herbicide phytotoxicity to crops by a physiological or molecular mechanism, without compromising weed control efficacy (Hatzios \& Burgos, 2004).

Herbicide safeners are used to protect several monocotyledonous crop species from herbicide injury, because they caused alterations on herbicide metabolism. Safeners might directly alter herbicide metabolism by chemically activating particular functional group(s) or by affecting enzymes involved in its metabolism (Fuerst et al., 1995). These compounds usually increase the activity of specific herbicide-metabolizing enzymes, such as glutathione S-transferase (GST, EC 2.5.1.18), P450-dependent monooxygenases, and glucosyltransferases, which lead to higher herbicide metabolism rate (Kreuz et al., 1996; Cummins et al., 1997; Abu-Qare \& Duncan, 2002; Brazier-Hicks et al., 2008; Liu et al., 2009).

Many studies have suggested that safeners can induce the activity of mixed-function oxidase enzymes. This induction may enhance herbicide oxidation and hydroxylation (Jablonkai \& Hatzios, 1994), but there is no conclusive evidence regarding the induction of these enzymes by any of the currently available safeners. Herbicide conjugation with reduced glutathione (GSH) is a common metabolic pathway, and the conjugation rate is related to plant tolerance to herbicides
(Cataneo et al., 2002, 2003; Andrews et al., 2005). Previous reports have demonstrated that safeners induce GST activity in plants (Andrews et al., 2005; Cummins et al., 2006; DeRidder \& Gouldsbrough, 2006). Thus, an increase not only in GSH content but also in the activity of GST, the enzyme that catalyzes herbicide conjugation to GSH, may lead to a higher rate of herbicide conversion into non-toxic metabolites. Therefore, conclusive elucidation of the mechanisms underlying safener action still remains a challenge.

The aims of this study were to: (a) examine lipid levels and GST activity in five wheat (Triticum aestivum) varieties having different tolerance levels to fenoxaprop-p-ethyl; (b) determine a possible relationship of lipid levels and/or GST activity and the tolerance of these varieties to fenoxaprop- $p$-ethyl; and (c) evaluate the effect of mefenpyr-diethyl safener on lipid levels and/or GST-mediated fenoxaprop- $p$-ethyl detoxification.

\section{MATERIAL AND METHODS}

\section{Plant material and growth conditions}

The experiment was carried out in a greenhouse at $30 \pm 3 / 20 \pm 3{ }^{\circ} \mathrm{C}$ day/night temperature with a photoperiod of about $14 \mathrm{~h}$. Seeds of BRS 49, CD 104, CEP 24, IAPAR 78 and Rubi wheat varieties were used. Twentyfive seeds of each variety were sown at $2 \mathrm{~cm}$ depth in $700 \mathrm{~mL}$ plastic pots filled with a soil mixture $(75 \%$ soil and $25 \%$ sand v/v). Pots were kept in greenhouse at $25^{\circ} \mathrm{C}$, and plants were watered when necessary. Plants were thinned to the most uniform fifteen seedlings per pot at 6 days after germination.

\section{Experimental design and treatments}

Experimental design was completely randomized in a $5 \times 4$ factorial arrangement, i.e., five wheat varieties and four treatments as fenoxaprop-p-ethyl plus mefenpyr-diethyl, fenoxaprop-p-ethyl, mefenpyr-diethyl and water control, with six replicates.

Commercial formulations including herbicide fenoxaprop- $p$-ethyl with safener (Puma S: fenoxaprop-p-ethyl 69 g a.i. $\mathrm{L}^{-1}$ plus mefenpyr-diethyl $18.75 \mathrm{~g}$ a.i. $\mathrm{L}^{-1}$ ), with no 
safener (Whip S: fenoxaprop- $p$-ethyl $69 \mathrm{~g}$ a.i. $\mathrm{L}^{-1}$ ), or the safener alone (mefenpyr-diethyl $18.75 \mathrm{~g}$ a.i. $\mathrm{L}^{-1}$ ) were applied using a motorized knapsack mist blower equipped with four flatfan nozzles (XR 110.02) spaced $50 \mathrm{~cm}$ apart, and calibrated to deliver $200 \mathrm{~L} \mathrm{ha}^{-1}$ at $310.27 \mathrm{kPa}$. Treatments were applied at sixteen days after planting.

\section{Visual evaluation of injury}

Injury to shoots (fifteen seedlings per pot) was visually assessed at 7 and 14 days after treatments (DAT). These evaluations were based on a percentage scale, in which zero and one hundred indicate no injury and death of all seedlings, respectively. The numbers between zero and one hundred represented different degrees of injury (such as chlorosis) and were given based on this scale 0 : no damage; 20: $20 \%$ of seedlings with chlorosis; 40: $40 \%$ of seedlings with chlorosis; $60: 60 \%$ of seedlings with chlorosis; $80: 80 \%$ of seedlings with chlorosis; and 100: complete death of seedlings.

\section{GST extraction and assay}

Shoot tissue samples (1.0 g) of both treated and control seedlings were harvested at 7 DAT, frozen in liquid nitrogen and stored at $-80{ }^{\circ} \mathrm{C}$ before analysis. Samples were washed with distilled water and superficially dried with filter paper. GST extraction was carried out according to the procedure of Knörzer et al. (1996). Shoot segments (1.0 g fresh matter) were powdered using a pestle and a cold mortar containing a small amount of quartz sand and $5 \mathrm{~mL}$ of $50 \mathrm{mM}$ Tris- $\mathrm{HCl}$ buffer, $\mathrm{pH} 7.0$, containing $20 \%\left(\mathrm{v} \mathrm{v}^{-1}\right)$ glycerol, $1 \mathrm{mM}$ ascorbic acid, $1 \mathrm{mM}$ dithiothreitol, $1 \mathrm{mM}$ EDTA, $1 \mathrm{mM}$ GSH and $5 \mathrm{mM} \mathrm{MgCl}_{2}$, including $1 \%\left(\mathrm{w} \mathrm{v}^{-1}\right)$ polyvinylpyrrolidone. After two centrifugation steps $(6 \mathrm{~min}$ at $12.000 \mathrm{x} \mathrm{g}$, and $16 \mathrm{~min}$ at $26.000 \times \mathrm{g}$ ) at $4{ }^{\circ} \mathrm{C}$, the supernatant was collected and used as crude extract to assess GST activity according to Wu et al. (1996) using 1 chloro-2,4-dinitrobenzene (CDNB) as substrate. Each reaction $(3 \mathrm{~mL})$ contained $30 \mu \mathrm{L}$ enzyme extract, $2 \mathrm{~mL} 100 \mathrm{mM}$ potassium phosphate buffer pH 6.9, $0.9 \mathrm{~mL} 3.3 \mathrm{mM}$ GSH $(0.9 \mathrm{~mL})$, and $100 \mu \mathrm{L} 30 \mathrm{mM} \mathrm{CDNB}$ in $96 \%$ ethanol. The mixture was incubated at $25^{\circ} \mathrm{C}$ for $60 \mathrm{~min}$. The reaction started after the addition of CDNB, and the change in absorbance due to the formation of glutathioneCDNB conjugate over time was measured spectrophotometrically at $340 \mathrm{~nm}$. The rate of change in absorbance obtained was then used to quantify the enzyme activity in the mixture using the molar extinction coefficient of glutathione-CDNB conjugate $\left(9.6 \mathrm{mM} \mathrm{cm}^{-1}\right)$. The enzyme activity was corrected using the nonenzymatic conjugation, which was determined through the same reaction without the crude plant extract. Specific GST activity was expressed as mmol $\mathrm{min}^{-1} \mathrm{mg}^{-1}$ protein. Protein concentrations in the shoot extracts were determined according to Lowry et al. (1951) using bovine serum albumin as standard.

\section{Lipid content}

Fifteen seedling shoots were harvested at 14 DAT for lipid percentage quantification in dry biomass according to the method proposed by the Association of Official Agricultural Chemists (AOAC), as described by Silva (1990).

\section{Statistical analysis}

Visual evaluation (percent injury) was statistically analyzed only for fenoxaprop- $p$ ethyl, because no injury was detected for any of the other treatments. GST activity and lipid percentage data were transformed in square root. ANOVA was performed to test the significance of the observed differences. Differences among varieties and chemical treatments were evaluated by the Duncan test, and p-values $\leq 0.05$ were considered statistically significant.

\section{RESULTS AND DISCUSSION}

Wheat varieties differed in their susceptibility to fenoxaprop-p-ethyl according to visual evaluation of plant injury at 7 and 14 DAT (Table 1). Crop injury (expressed as chlorosis and sometimes death) increased in all wheat varieties from 7 to 14 DAT. Varieties CD 104 and BRS 49 were most susceptible to fenoxaprop- $p$-ethyl, whereas the variety Rubi was the most tolerant one. None of the wheat varieties showed symptoms of phytotoxicity at 
Table 1 - Injury of shoots of Triticum aestivum varieties associated with the application of fenoxaprop- $p$-ethyl ${ }^{1 /}$

\begin{tabular}{|l|c|c|}
\hline \multicolumn{3}{|c|}{ Days after application } \\
\hline \multicolumn{1}{|c|}{ Variety } & $7^{2 /}$ & 14 \\
\hline BRS 49 & $16.33 \pm 1.97 \mathrm{~B}^{\underline{3} /}$ & $31.67 \pm 2.58 \mathrm{~B}$ \\
\hline CD 104 & $27.67 \pm 2.25 \mathrm{~A}$ & $57.17 \pm 2.48 \mathrm{~A}$ \\
\hline CEP 24 & $9.17 \pm 0.98 \mathrm{C}$ & $13.00 \pm 2.45 \mathrm{C}$ \\
\hline IAPAR 78 & $8.00 \pm 0.00 \mathrm{C}$ & $9.50 \pm 0.55 \mathrm{D}$ \\
\hline Rubi & $3.83 \pm 0.98 \mathrm{D}$ & $6.33 \pm 1.51 \mathrm{E}$ \\
\hline
\end{tabular}

to 100 (complete death); ${ }^{2}$ Data represent the mean \pm S.E. of six replicates; ${ }^{3}$ Means followed by the same letter in column did not differ significantly according to Duncan's test. Standard error $=1.7962 ; \alpha=0.05 ; \mathrm{CV}=9.83 \%$; Degrees of freedom $=50$.

7 and 14 DAT with fenoxaprop-p-ethyl plus mefenpyr-diethyl or the safener alone.

Wheat varieties differed in their natural GST activity in the absence of treatment (Table 2). Wheat plants from CD 104 and CEP 24 varieties treated only with fenoxaprop$p$-ethyl had $\sim 2$-fold higher GST activity relative to the untreated controls. Compared with control plants, GST activity in the BRS 49, IAPAR 78 , and Rubi varieties, increased by $72 \%, 50 \%$, and $37 \%$, respectively over control. For all tested varieties except BRS 49, the treatment involving mefenpyr-diethyl safener plus fenoxaprop- $p$-ethyl led to decreased GST activity in plants as compared with the treatment using fenoxaprop- $p$-ethyl only. The treatment with mefenpyr-diethyl safener only led to decreased GST activity in all varieties compared with those plants treated only with fenoxaprop- $p$-ethyl. The GST activity in the BRS 49, CD 104 and IAPAR 78 varieties treated with the safener alone decreased relative to the mefenpyr-diethyl plus fenoxaprop-p-ethyl treatment, whereas the activity in CEP 24 and Rubi increased.

Herbicide selectivity is frequently based on the ability of crops to detoxify these compounds (Cummins et al., 1997). The conjugation of herbicides with GSH is an important and irreversible mode of detoxification catalyzed by GSTs. However, the highest GST activities measured in the wheat varieties BRS 49 and CD 104 did not reveal more tolerance to fenoxaprop- $p$-ethyl, because visual evaluations indicated that these varieties had higher susceptibility to this herbicide (Table 1). These results are contradictory to those of Wu et al., (1996) who considered that an increase in GST activity in wheat is one of the mechanisms responsible for fenoxaprop- $p$ ethyl detoxification, improving tolerance to the herbicide. Furthermore, field populations of the black-grass weed (Alopecurus myosuroides Huds.), which are more resistant to fenoxaprop- $p$-ethyl, had higher GST activities than populations susceptible to this herbicide (Cocker et al., 1999).

Based on the relationship between high GST activity and wheat seedling tolerance to the herbicide dimethenamid, GST activity was used as a biochemical marker for such tolerance (Riechers et al., 1996). However, this is not true for fenoxaprop- $p$-ethyl, because no

Table 2 - GST activities $^{1 /}$ of wheat cultivars shoots at 7 DAT

\begin{tabular}{|l|c|c|c|c|}
\hline \multicolumn{5}{|c|}{ Treatments } \\
\hline Variety & Untreated/Control ${ }^{2 /}$ & $\begin{array}{c}\text { Fenoxaprop- } p \text {-ethyl } \\
\left(69 \mathrm{~g} \mathrm{ha}^{-1}\right)\end{array}$ & $\begin{array}{c}\text { Fenoxaprop- } p \text {-ethyl }+ \\
\text { mefenpyr-diethyl } \\
\left(69 \mathrm{~g}+18.75 \mathrm{~g} \mathrm{ha}^{-1}\right)\end{array}$ & $\begin{array}{c}\text { Mefenpyr-diethyl } \\
\left(18.75 \mathrm{~g} \mathrm{ha}^{-1}\right)\end{array}$ \\
\hline BRS 49 & $62.50 \pm 4.77 \mathrm{~A}^{3} \mathrm{~b}$ & $107.66 \pm 12.89 \mathrm{~B} \mathrm{a}$ & $106.38 \pm 15.14 \mathrm{~A} \mathrm{a}$ & $56.38 \pm 7.43 \mathrm{~B} \mathrm{~b}$ \\
\hline CD 104 & $64.74 \pm 2.82 \mathrm{~A} \mathrm{c}$ & $129.38 \pm 7.78 \mathrm{~A} \mathrm{a}$ & $98.42 \pm 13.98 \mathrm{~A} \mathrm{~b}$ & $41.03 \pm 3.94 \mathrm{C} \mathrm{d}$ \\
\hline CEP 24 & $44.64 \pm 4.58 \mathrm{C} \mathrm{c}$ & $84.34 \pm 8.13 \mathrm{C} \mathrm{a}$ & $45.65 \pm 2.85 \mathrm{C} \mathrm{c}$ & $65.98 \pm 7.98 \mathrm{~A} \mathrm{~b}$ \\
\hline IAPAR 78 & $48.48 \pm 4.71 \mathrm{BC} \mathrm{b}$ & $72.93 \pm 11.92 \mathrm{D} \mathrm{a}$ & $54.46 \pm 2.59 \mathrm{~B} \mathrm{~b}$ & $39.88 \pm 1.47 \mathrm{C} \mathrm{c}$ \\
\hline Rubi & $50.20 \pm 2.92 \mathrm{~B} \mathrm{~b}$ & $68.69 \pm 5.63 \mathrm{D} \mathrm{a}$ & $43.15 \pm 3.63 \mathrm{C} \mathrm{c}$ & $52.98 \pm 7.06 \mathrm{~B} \mathrm{~b}$ \\
\hline
\end{tabular}

${ }^{1 /}$ GST activity is defined as mmol $\mathrm{min}^{-1}$ per $\mathrm{mg}$ protein; ${ }^{2 /}$ Data represent the mean \pm S.E. of six replicates; ${ }^{3 /}$ Means followed by the same letter (uppercase in column and lowercase in row) did not differ significantly according to Duncan's test. Standard error $=0.4307 ; \alpha=0.05$; $\mathrm{CV}=5.36 \%$; Degrees of freedom $=100$. 
relationship between tolerance and high GST activity was found for the varieties studied in this present work (Table 2).

It has been demonstrated in wheat that the metabolism of diclofop, which has the same mechanism of action as fenoxaprop- $p$ ethyl, may be mediated by different enzymes, possibly P450-dependent monooxygenases, and the role of GST in diclofop metabolism in wheat has not been demonstrated (Romano et al., 1993). However, the selectivity of the aryloxyphenoxy propionate herbicide class can be increased with the addition of specific safeners. Studies have shown that safenerinduced catabolism of fenoxaprop- $p$-ethyl is associated with an increase in GST activity (Cummins et al., 1997).

Our results indicated that the mefenpyrdiethyl safener applied alone and in premix with fenoxaprop- $p$-ethyl was not responsible for inducing GST activity. According to Matola \& Jablonkai (2007), the protective efficacy of dichloroketal safeners in maize does not seem to be associated with enhanced herbicide detoxification by glutathione conjugation. On the other hand, several studies have reported that safeners increase herbicide tolerance given that they selectively induce GST activity. Therefore, safeners lead to a high detoxification rate through conjugation with glutathione (Hatzios \& Wu, 1996; Kreuz et al., 1996; Marrs, 1996; Hess \& Weller, 2000). It should also be taken into account that GSTs include constitutive isozymes as well as safener-inducible isozymes (Potter et al., 1995).
Mefenpyr-diethyl is a molecule that has been recently replaced by fenchlorazoleethyl as a safener for fenoxaprop-p-ethyl in wheat crops. Yaacoby et al. (1991) used the commercial formulation of fenoxaprop- $p$-ethyl with the safener fenchlorazole (fenoxaprop- $p$ ethyl $60 \mathrm{~g}$ a.i. $\mathrm{L}^{-1}$ plus fenchlorazole $15 \mathrm{~g} \mathrm{~L}^{-1}$ ) at the same concentration used in this present study (fenoxaprop-p-ethyl $60 \mathrm{~g}$ a.i. $\mathrm{L}^{-1}$ plus mefenpyr-diethyl $18.75 \mathrm{~g}$ a.i. $\left.\mathrm{L}^{-1}\right)$. According to these authors, the safener might protect wheat plants from the phytotoxic action of fenoxaprop- $p$-ethyl by increasing both the deesterification rate of fenoxaprop- $p$-ethyl to fenoxaprop and the metabolism of fenoxaprop to other metabolites.

Lipid content differed among the wheat varieties (Table 3). Relative to control plants, the lipid content was lower in all wheat varieties (except for IAPAR 78) treated only with fenoxaprop- $p$-ethyl, and major reductions in lipid content were found in CD 104 (72\%) and BRS 49 (63\%). Fenoxaprop-p-ethyl plus mefenpyr-diethyl increased lipid content in all varieties compared to plants treated with fenoxaprop- $p$-ethyl alone; whereas mefenpyrdiethyl used alone led to the greatest increase in lipid content. With regard to the protective action of the safener mefenpyr-diethyl, the premix with fenoxaprop- $p$-ethyl increased the lipid content compared to the fenoxaprop- $p$ ethyl treatment alone.

Based on the results of lipid content (Table 3) correlated with the visual injury (Table 1), BRS 49 and CD 104 are probably the wheat varieties that are most susceptible

Table 3 - Lipid content as a percentage of wheat cultivars shoots at 14 DAT

\begin{tabular}{|c|c|c|c|c|}
\hline \multicolumn{5}{|c|}{ Treatments } \\
\hline Variety & Untreated/ Control $^{1 /}$ & $\begin{array}{l}\text { Fenoxaprop- } p \text {-ethyl } \\
\qquad\left(69 \mathrm{~g} \mathrm{ha}^{-1}\right)\end{array}$ & $\begin{array}{c}\text { Fenoxaprop- } p \text {-ethyl }+ \\
\text { mefenpyr-diethyl } \\
\left(69 \mathrm{~g}+18.75 \mathrm{~g} \mathrm{ha}^{-1}\right)\end{array}$ & $\begin{array}{l}\text { Mefenpyr-diethyl } \\
\quad\left(18.75 \mathrm{~g} \mathrm{ha}^{-1}\right)\end{array}$ \\
\hline BRS 49 & $8.27 \pm 0.16 \mathrm{BC}^{2} / \mathrm{c}$ & $3.03 \pm 0.10 \mathrm{C} \mathrm{d}$ & $10.30 \pm 0.50 \mathrm{~A} \mathrm{~b}$ & $11.45 \pm 0.28 \mathrm{C} \mathrm{a}$ \\
\hline CD 104 & $8.56 \pm 0.44 \mathrm{BC} \mathrm{b}$ & $2.47 \pm 0.14 \mathrm{D} \mathrm{c}$ & $8.56 \pm 0.18 \mathrm{C} \mathrm{b}$ & $9.33 \pm 0.08 \mathrm{E} \mathrm{a}$ \\
\hline CEP 24 & $11.06 \pm 0.34 \mathrm{~A} \mathrm{~b}$ & $9.31 \pm 0.12 \mathrm{~A} \mathrm{c}$ & $11.06 \pm 0.50 \mathrm{~A} \mathrm{~b}$ & $15.33 \pm 0.15 \mathrm{~A} \mathrm{a}$ \\
\hline IAPAR 78 & $8.65 \pm 0.40 \mathrm{~B} \mathrm{c}$ & $8.11 \pm 0.69 \mathrm{~A} \mathrm{c}$ & $10.77 \pm 0.61 \mathrm{~A} \mathrm{~b}$ & $13.50 \pm 0.12 \mathrm{~B} \mathrm{a}$ \\
\hline Rubi & $8.16 \pm 0.34 \mathrm{C} \mathrm{c}$ & $6.99 \pm 0.08 \mathrm{~B} \mathrm{~d}$ & $9.61 \pm 0.06 \mathrm{~B} \mathrm{~b}$ & $10.70 \pm 0.21 \mathrm{D}$ a \\
\hline
\end{tabular}

${ }^{1 /}$ Data represent the mean \pm S.E. of six replicates; ${ }^{2} /$ Means followed by the same letter (uppercase in column and lowercase in row) did not differ significantly according to Duncan's test. Standard error $=0.0543 ; \alpha=0.05 ; \mathrm{CV}=1.81 \%$; Degrees of freedom $=100$. 
to the action of fenoxaprop- $p$-ethyl. Thus, lipid level quantification can be used as a biochemical marker for herbicide susceptibility. Fenoxaprop-p-ethyl acts as a lipid biosynthesis inhibitor (Vidal \& Merotto Jr., 2001). In the present study, lipid levels increased in plants treated with mefenpyrdiethyl alone and also in those subjected to herbicide plus safener (Figure 2 and Table 3), suggesting that mefenpyr-diethyl safener protects plants by enhancing lipid biosynthesis. These results suggest that the mechanism of action of mefenpyr-diethyl is related to lipid content increase. Mefenpyr-diethyl probably plays a protective role by altering cuticle and plasma membrane composition. Hess \& Weller (2000) reported that only 1-6\% fenoxaprop- $p$ ethyl can translocate through the plant vascular system and that any decrease in this translocation rate may lead to higher tolerance to the herbicide in wheat.

In conclusion, our results demonstrate that lipid quantification can be used to determine the differential susceptibilities of wheat varieties to fenoxaprop-p-ethyl. This quantification will be useful in future studies to detect the lowest lipid levels in response to herbicide treatment, quickly identifying the highest tolerance of wheat varieties to the herbicide. Thus, this criterion can be used to screen new varieties developed through genetic methods. Furthermore, this biochemical evaluation can be used to select appropriate safeners for the aryloxyphenoxy propionic acid chemical family and to identify resistant weeds tolerant to this herbicide class. Although the development of herbicide safeners and the understanding of their mechanisms of action have advanced, further studies are needed to clarify how these chemicals act at the molecular level to protect plants against herbicide injury.

\section{LITERATURE CITED}

ABU-QARE, A. W.; DUNCAN, H. J. Herbicide safeners: uses, limitations, metabolism, and mechanisms of action. Chemosphere, v 48, n. 9, p. 965-974, 2002

ANDREWS, C. J. et al. Purification and characterisation of a family of glutathione transferases with roles in herbicide detoxification in soybean (Glycine max L.); selective enhancement by herbicides and herbicide safeners. Pestic. Biochem. Physiol., v. 82, n. 3, p. 205-219, 2005
BRAZIER-HICKS, M. et al. Catabolism of glutathione conjugates in Arabidopsis thaliana: role in metabolic reactivation of the herbicide safener-fenclorim. J. Biol. Chem., v. 283, n. 30, p. 21102-2112, 2008.

CATANEO, A. C. et al. Glutathione S-transferase activity in acetochlor, atrazine and oxyfluorfen metabolization in maize (Zea mays L.) sorghum (Sorghum bicolor L.) and wheat (Triticum aestivum L.) (Poaceae). Acta Sci., v. 24, n.2, p. 619-623, 2002.

CATANEO, A. C. et al. Atividade de glutationa S-transferase na degradação do herbicida glyphosate em plantas de milho

(Zea mays). Planta Daninha, v. 21, n. 2, p. 307-312, 2003

COCKER, K. M.; MOSS, S. R.; COLEMAN, J. O. D. Multiple mechanisms of resistance to fenoxaprop-p-ethyl in United Kingdom and other European populations of herbicide-resistant Alopecurus myosuroides (black-grass). Pestic. Biochem. Physiol., v. 65, n. 3, p. 169-180, 1999.

CUMMINS, I.; COLE, D. J.; EDWARDS, R. Purification of multiple glutathione transferases involved in herbicide detoxification from wheat (Triticum aestivum $\mathrm{L}$.) treated with the safener fenchlorazole-ethyl. Pestic. Biochem. Physiol., v. 59, n. 1, p. 35-49, 1997.

CUMMINS, I. et al. Selective disruption of wheat secondary metabolism by herbicide safeners. Phytochemistry, v. 67, n. 16, p. 1722-1730, 2006.

DeRIDDER, B. P.; GOULDSBROUGH, P. B. Organspecific expression of glutathione $\mathrm{S}$-transferases and the efficacy of herbicide safeners in Arabidopsis. Plant Physiol. v. 140, n. 1, p. $167-175,2006$

FUERST, E. P. et al. Mechanism of action of the herbicide safener benoxacor in maize. Pestic. Sci., v. 43, n. 3, p. 242-244, 1995.

GRONWALD, J. W. Lipid biosynthesis inhibitors Weed Sci., v. 39, n. 3, p. 435-449, 1991

HATZIOS, K. K.; BURGOS, N. Metabolism-based herbicide resistance: regulation by safeners. Weed Sci., v. 52, n. 3, p. 454-467, 2004.

HATZIOS, K. K.; WU, J. Herbicide safeners: tools for improving the efficacy and selectivity of herbicides. J. Environ. Sci. Health, v. 31, n. 3, p. 545-553, 1996.

HESS, F. D.; WELLER, S. C. Principles of selectivity weed control with herbicides. In: Herbicide action course; summary of lectures. West Lafayette: Purdue University, 2000. p. $306-333$.

JABLONKAI, I.; HATZIOS, K. K. Microsomal oxidation of the herbicides EPTC and acetochlor and of the safener MG191 in maize. Pestic. Biochem. Physiol., v. 48, n. 2, p. $98-109,1994$ 
KNÖRZER, O.C.; DURNER, J.; BÖGER, P. Alterations in the antioxidative system of suspension-cultured soybean cells (Glycine max) induced by oxidative stress. Physiol. Plant., v. 97, n. 2 , p. $388-396,1996$.

KREUZ, K.; TOMMASINI, R.; MARTINOIA, E. Old enzymes for a new job. Herbicide detoxification in plants. Plant Physiol., v. 111, n. 2, p. 349-353, 1996.

LIU, J.; BRAZIER-HICKS, M.; EDWARDS, R. A kinetic model for the metabolism of the herbicide safener fenclorim in Arabidopsis thaliana. Biophys. Chem., v. 143, n. 12 , p. 85-94, 2009

LOWRY, O. H. et al. Protein measurement with Folin-phenol reagent. J. Biol. Chem., v. 193, n. 1, p. 265-275, 1951.

MARRS, K. A. The functions and regulation of glutathione S-transferases in plants. Ann. Rev. Plant Physiol. Plant Molec. Biol., v. 47, p. 127-158, 1996.

MATOLA, T,; JABLONKAI, I. Safening efficacy of halogenated acetals, ketals and amides and relationship between the structure and effect on glutathione and glutathione S-transferases in maize. Crop Protec., v. 26, n. 3 , p. 278-284, 2007.

POTTER, S. et al. Induction of cytochrome P450 genes by ethanol in maize. Drug Metabol. Drug Interac., v. 12, n. 3-4, p. 317-327, 1995.
RIECHERS, D. E. et al. Variability of glutathione S-transferase levels and dimethenamid tolerance in safenertreated wheat and wheat relatives. Pestic. Biochem.

Physiol., v. 56, n. 2, p. 88-101, 1996.

ROMANO, M. L. et al. The effect of monooxygenase and glutathione S-transferase inhibitors on the metabolism of diclofop-methyl and fenoxaprop-ethyl in barley and wheat. Pestic. Biochem. Physiol., v. 46, n. 3, p. 181-189, 1993.

SILVA, D. J. Determinação da gordura bruta ou extrato etéreo. In: SLVA, D. J. (Ed.). Análise de alimentos; métodos químicos e biológicos. 2.ed. Viçosa, MG: Imprensa Universitária, UFV, 1990. p. 12-14.

VIDAL, R. A.; MEROTTO JR., A. Inibidores de ACCase. In: VIDAL, R. A.; MEROTTO, J. R. (Ed.). Herbicidologia. Porto Alegre: Evangraf, 2001. p. 15-24.

WU, J.; OMOKAWA, H.; HATZIOS, K. K. Glutathione $\mathrm{S}$-transferase activity in unsafened and fenclorim-safened rice (Oryza sativa). Pestic. Biochem. Physiol., v. 54, n. 3, p. 220-229, 1996.

YAACOBY, T.; HALL, J. C.; STEPHENSON, G. R. Influence of fenchlorazole-ethyl on the metabolism of fenoxaprop-ethyl in wheat, barley, and crabgrass. Pestic. Biochem. Physiol., v. 41, n. 3, p. 296-304, 1991. 